\title{
Ghost Stories
}

\author{
DEANE WiLLIAMS
}

\section{Ross Gibson}

The Summer Exercises

University of Western Australia Press

ISBN 9781921401206

RRP \$24.95 (pb)

Swarming city—city gorged with dreams, where ghosts by day accost the passer-by.

Charles Baudelaire, 'Les Sept Vieillards'1

Back in 1986, Ross Gibson was interviewed in Filmnews by Adrian Martin and Tina Kaufman about his experimental short essay film Camera Natura (1984). ${ }^{2}$ Accompanying that interview was a photo of Gibson 'on location' for his film, wearing a hat not unlike the one that features on the cover of his new book The Summer Exercises. Back then I understood the hat to be an explorer's, someone like Charles Sturt, someone whose willingness to learn from his environment had impressed Gibson in fashioning his own history of Australian landscape imaging. Now the hat looks like a detective's or, rather, Marcel Duchamp's rendering of a detective's hat: on display, ready for our re-consideration. 
The Summer Exercises is Gibson's literary iteration of his and Kate Richards' Life After Wartime Suite series, which has included the Crime Scene exhibition at the Justice and Police Museum, Sydney in 1999, the improvised performance Life After Wartime Live with The Necks (2002-03), and the Life After Wartime CD-rom (2004). ${ }^{3}$ Published in the University of Western Australia Press's New Writing series, which 'encourages the ongoing production of creative and speculative writing by new and established Australian authors', Gibson's latest book is a poetic and aleatory work of improvisation, a lyrical rendering of a story sparked by a decade or so of finding a means of expression in a jumble of images, many alone, unbounded by tags, or titles or names. The book, like the rest of the suite, seeks out the ghosts of Sydney Town after World War II, a city recovering from the war yet still awash with its unpleasantness, its loneliness and its uncertainty. Divining from these photos some sense of place and environment, Gibson characterises his investigation by means of a civilian chaplain, a persona that lends itself well to confession, to intuition and to a graceful appreciation of the senses. The Summer Exercises therefore relies on a slight narrative, something upon which to build a swirl of metaphors and analogies, of suggestive images that embed the reader in a Sydney that is historical at the same time as it is contemporary.

In his 'The Work of Art in the Age of Mechanical Reproduction' Walter Benjamin recalls that Eugène Atget's images of deserted Paris streets had been photographed 'like scenes of a crime' and that:

with Atget, photographs become standard evidence for historical occurrences, and acquire political significance. They demand a specific kind of approach; free-floating contemplation is not appropriate to them.

They stir the viewer; he feels challenged by them in a new way. 4

In another history, not unlike the one Gibson had told about Australian landscape imagery, the surrealists made much of Giorgio de Chirico's images of a superficial neo-classicism that went on to influence the work of Raoul Ubac, Yves Tanguy and other painters of Paris. This lineage continued on to Jacques-André Boiffard's realist photographs of various monuments and of course to Atget's own 'crime-scene' photography.

Another way to approach The Summer Exercises is, of course, via Luc Sante's wonderful book Evidence. ${ }^{5}$ Born out of a similar enquiry to Gibson's, Sante 
ruminates on the meanings of a series of crime-scene photographs for what he terms a 'great city such as New York'. ${ }^{6}$ Sante describes the multitude of archives in New York as containing:

dissertations that will never be read, codes that will never be deciphered, objects whose particular import will never be understood, and the traces of innumerable human beings lost to history once and for all, without monuments or descendants or living memory, just a name somewhere in an official record consulted rarely if at all. ${ }^{7}$

Like Gibson, Sante grasps at these images in order to see what meanings may arise. Like Gibson, Sante's writing is evocative and inspiring, empathic and graceful, writing lines that are like wisps of threads, laying out miniature trails of song-like lyrics across Australia's metropolis. Unlike Gibson, Sante, in Low Life: Lures and Snares of Old New York, has images of violence: of gunshot and razors and the blood and horror, a kind of noir aesthetic emblematic of the American city but also a fascination born from his magisterial portrait of the slums and street life of Manhattan around of the turn of last century. ${ }^{8}$ That is, Sante brings a different perspective to New York than the one Gibson brings to Sydney. While both authors are 'at home' in their respective metropolises, Gibson's task is different. Unhindered by the scores of stories that wend their way up and down and across Manhattan in an endless mythologising of that city's street life, Sydney, because of its size, its population and its own (mainly foundational) mythology, cries out for the kinds of stories that Gibson spins. Gibson's tales are also spectral and speculative, risking specificity and science to get at the ghosts that haunt these photos.

In this way Gibson's book is a collection of ghost stories, spectral tales that get to the heart of the city haunted by a history of violence, of unease, of unruliness and oceanic influences. The setting of these tales in the summer heat provides a briny antipodean intensity to the images Gibson provides, as well as those he refers to, strengthening the tenor of the ghost stories:

This stifling day hits its zenith. Heat thick with humidity is lurking at the window-sills. Sweat is smudging every eyelid and lip. A few hours away, a downpour will come and rearrange the air. But it's lunchtime right now and the electric fans are all blowing.

Nothing else is moving. (16) 
This stilled image suggests endlessness. Outside the frame postwar Sydney bustles and rumbles, attended to by Gibson's prose. The photo images that Gibson includes in the book are really stilled pretexts to the sense of a city teeming with people, a continuation of the clamour that resounded there since settlement. For Gibson it is the ghosts that follow that busy-ness, the ghosts and their stories that adhere to places long after official history has moved on.

Deane Williams is an associate professor in Film and Television Studies at Monash University, Melbourne. He is editor of Studies in Documentary Film and author of Australian Post-War Documentary Films: An Arc of Mirrors (2008) and, with Brian McFarlane, Michael Winterbottom (2009).<Deane.Williams@arts.monash.edu.au>

\footnotetext{
-NOTES

${ }^{1}$ At this stage I must confess to reading Ian Walker's brilliant City Gorged With Dreams: Surrealism and Documentary Photography in Interwar Paris, Manchester University Press, Manchester and New York, 2002 alongside The Summer Exercises.

${ }^{2}$ Adrian Martin and Tina Kaufman, 'Bushed', interview with Ross Gibson, Filmnews, vol. 16, no. 5, October 1986, pp. 9-10.

${ }^{3}$ Ross Gibson and Kate Richards, Life After Wartime, Australian Film Commission, Australia Council, University of Technology, Sydney, 2003.

${ }^{4}$ Walter Benjamin, 'The Work of Art in the Age of Mechanical Reproduction' in Benjamin, Illuminations. ed. Hannah Arendt, Shocken Books, New York, 1968, p. 226.

${ }^{5}$ Luc Sante, Evidence, second edition, Farrar, Straus and Giroux, New York, 1992.

${ }^{6}$ Sante, Evidence, p. ix.

${ }^{7}$ Sante, Evidence, p. ix.

${ }^{8}$ Luc Sante, Low Life: Lures and Snares of Old New York, Farrar, Straus and Giroux, New York, 1991.
} 